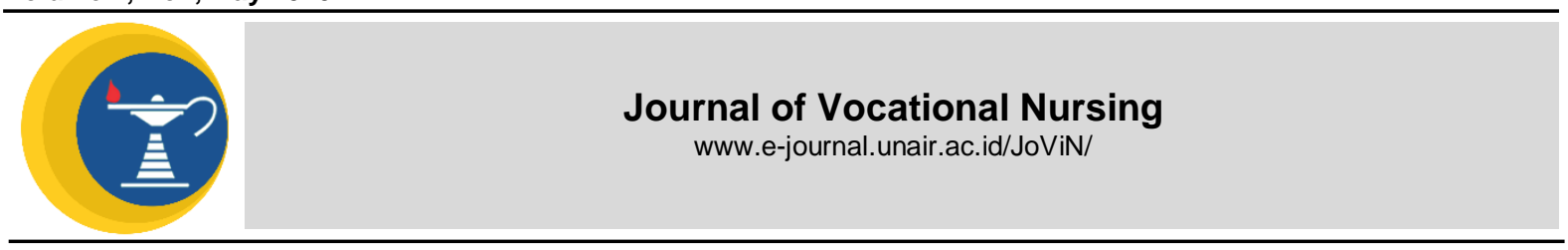

\title{
CORRELATIONS OF GIVING DESINFECTION (ALCOHOL SWAB) WHEN GIVING INTRAVEIN INJECTION WITH PHLEBITIS
}

Research Report

\author{
Rindayanti \\ DIII Nursing Study Program, Departement of Health, Faculty of Vocational Studies, Universitas \\ Airlangga
}

\section{A B STRACT}

Introduction: Phlebitis is inflammation of the veins caused by chemical irritations of additives and drugs that are given intravenously. Phlebitis is characterized by the presence of a red and warm area around the area of stabbing or along the vein. This study aims to determine the effect of disinfection (alcohol swab) on intravenous bolus injection with phlebitis.

Methods: The research design used in this study is pre-experiment (Static Group Comparison). In this study the population was all patients who received intravenous bolus therapy. The sample in this study were some patients who received intravenous bolus therapy who met the inclusion criteria. Sampling in this study was simple random sampling with a total sample of 52 respondents.

Results: From the Chi Square Test $x 2=17,333$ and $p=0,00$ because $p<0$. $(0,00<0,05)$ then $\mathrm{HO}$ is rejected which means there is an influence of disinfection of alcohol swab during intravenous bolus injection with phlebitis occurrence. The number of respondents in the control group who did not / without using alcohol swab almost all respondents had phlebitis (84.6\%) and only a small number did not occur phlebitis (15.3\%) while respondents who were given alcohol swab during injection via intravenous bolus almost all phlebitis did not occur (92.3\%) and a small proportion occurred phlebitis (7.6\%).

Conclusion: Based on the results of the study, can be concluded that there is an influence of alcohol swab during intravenous injection with the occurrence of plebebitis. The effort that can be done to prevent phlebitis is aseptic technique in the area of insertion and disinfection that is strong in medical devices, observation of signs and symptoms of phlebitis, infusion catheter must be replaced if it is installed $>27$ hours.
ARTICLE INFO

Recived 23 December 2019

Accepted 9 May 2020

Online 29 May 2020

*Correspondence:

Rindayanti

*Email:

rindayati2501@gmail.com

Keywords:

Alcohol Swab, Disinfection, Plhebitis

\section{INTRODUCTION}

Hospital is somewhere sick people explained and in this place get clients therapy and care for get healing. But hospital besides to search healing, also is sources for various kinds diseases originating from clients also from visitors career status. Germ disease can live and develop in Hospital environment, such as; air, air, floor, food and tools - medical or nonmedical devices risk of nosocomial infection (Ari, 2009).

Infusion therapy is the most action often performed on patients who undergo hospitalized as an intravenous (IV) therapy pathway, drug administration, fluids, and product delivery blood, or blood sampling
(Alexander, Corigan, Gorski, Hankins, \& Perucca, 2010).

Prevention and control of nosocomial infections is a challenge throughout the world because it can increase morbidity and mortality and increase health costs due to additional time for treatment and hospital care. The prevalence of nosocomial infections in developing countries with resources is limited to more than $40 \%$. Control of nosocomial infections in hospitals is one effort to improve the quality of hospital services to the community by using the incidence of nosocomial infections as an indicator (Thirmanidana, 2018). 
Disinfection can use antiseptic solutions such as povidone iodine, $70 \%$ alcohol, or chlorexidinie. Disinfection skin is done by vertical movement, then horizontal, and ends with a circular motion from the inside come out with a diameter of 2 to 3 invhi for 20 seconds. After let the antiseptic fluid dry out (Perry and Potter, 2009; NHS, 2014).

Aseptic techniques (disinfection) that are lacking when installing an intravenous device can result in contamination by hand in the insertion area (Culverwell, 2013). Sterility principle indispensable in implementation of giving therapy by infusion because of the action administration of parenteral fluid therapy can damage one system body defense, namely the system integument (Asmadi, 2008). Because there was a significant relationship between the installation disinfection technique and the incidence of phlebitis (Istiroha, 2017).

When the skin is penetrated by the needle then the patient is the host susceptible to microorganisms endogenous and exogenous resistant and enter the body so that cause an infection in the vein, then the body will react by activating the mechanism marked body defense with signs of inflammation (Potter \& Perry, 2010).

Results of research by Wahyunah (2013) on the level of knowledge nurses about infusion therapy note that $50.8 \%$ have no knowledge well. This shows that it is still low knowledge of nurses about infusion therapy, especially those relating to principles vein selection and skin aseptic action before performing IV catheter insertions.

Infusion Nursing Society (INS 2011), phlebitis is an inflammation of the tunica intima of veins, which is often reported as a complication of infusion therapy. Inflammation is obtained from the mechanism of irritation that occurs in the tunic intima endhothelium, and platelet attachment in the area.

Standard precautions are a key combination of universal precautions (designed to reduce the risk of blood-borne pathogen transmission from blood and body fluids) and isolation of body substances (designed to reduce the risk of disease transmission from moist body substances (Elmiyasna, 2012).

Infusion therapy as one of the invasive measures requires sufficient skills when installing. As a result of improper installation procedures, incorrect positions, failure to insert veins, as well as instability in installing fixations, all of these can cause discomfort to the patient. In addition, the infusion of infusion can also cause complications of phlebitis. The cause of phlebitis is most often due to incompatibility of measurements and selection of venous location, type of fluid, lack of adhesion, and prolonged duration (Alexander, et al., 2010).

One of the important aspects in fluid therapy is Phlebitis. Simple Phlebitis means venous inflammation. The phlebitis is almost always following a blood pressure, or the thrombus in the diseased vein. Condicides are similar to the thrombosis of Hyperebitis. In more technical terms, Phlebitis results in the formation of cancer and pain, screaming, swelling, hardening, erythema, warmth (Graber, 2010).

In Indonesia there are no conditions which are of course related to the incidence of phlebitis, which may be caused by research and publications relating to phlebitis rarely carried out. Data Depkes RI in 2013, occurring in Phlebitis in Indonesia, amounted to $50.11 \%$ for the Hospital of Government while for Hospital of Hospital, $32.70 \%$.

The number of phlebitis occurrences according to the initial data from the study "Relationship of Frequency of Medication Distribution in Phlebitis Events" by Setyowati (2011) is 10,628 people in RSUD Ibnu Sina Gresik.

Components that are very important in standard precautions are disinfection and sterilization. Disinfection is a measure of action to kill peptogens and whether the concentration is not transported in treatment devices or surface tissues (Elmiyasna, 2012).

Based on the previous analysis, in the treatment of intravenous fluids it must determine the exact location of the vein of the lower arm or hand. Avoiding exposure to the challenge because it mobilizes is also recommended (Iradiyanti, 2013).

Teaches patients to monitor the infusion system, such as avoiding sudden movements of the back of the infectious arm, avoiding the tension in the hose can also be done by the nurse to prevent phlebitis (Berman, 2009).

\section{MATERIALS AND METHODS}

Design in this study is in fact a Case Control, which studies compare the groups of cases with group controls to find out the proportions of events based on history and not exposure. The research design is identified with a retrospective nature, which is a designation by looking behind the events that relate to the disease events studied.

The sample in this study is the large proportion of patients who received intravenous therapy at the study site, with criteria: adult men, getting intravenous therapy, 
compositional awareness, and getting

to be respondents. Data collection in this study uses direct observations to respondants who get intravenous therapy.

\section{RESULTS}

Table 1 Distribution of Respondents by age

\begin{tabular}{|c|c|c|c|}
\hline No & Age & Frequency & Percentage \\
\hline 1 & $20-39$ & 30 & 57,7 \\
\hline $\begin{array}{l}2 \\
3\end{array}$ & $\begin{array}{l}40-64 \\
65-79\end{array}$ & $\begin{array}{c}22 \\
0\end{array}$ & $\begin{array}{c}42,3 \\
0\end{array}$ \\
\hline 4 & $>80$ & 0 & 0 \\
\hline \multicolumn{2}{|c|}{ Total } & 52 & 100 \\
\hline
\end{tabular}

Shows the that the majority of respondents aged 20-39 years were 30 respondents and none of the respondents were over 65 years old.

Table 2 Distribution of Respondents Distribution of Respondents by Gender

\begin{tabular}{|c|c|c|c|}
\hline No & Gender & Frequency & Percentage \\
\hline 1 & Male & 35 & 67,3 \\
\hline 2 & Female & 17 & 32,7 \\
\hline \multicolumn{2}{|c|}{ Total } & 52 & 100 \\
\hline
\end{tabular}

Shows that most of the male sex were 35 respondents. And a small number of respondents were female as many as 17 respondents.

Table 3 Distribution of Respondents by Type of Disease

\begin{tabular}{cccc}
\hline No & Type of Disease & Frequency & Percentage \\
\hline 1 & Chronic Disease & 18 & 34,6 \\
2 & Acute Disease & 11 & 21,1 \\
3 & Infectious Disease & 7 & 13,6 \\
4 & Non Infectious Disease & 3 & 5,7 \\
5 & Traumatic Disease & 13 & 25 \\
\hline & Total & 53 & 100
\end{tabular}

Shows that most of the diseases experienced by respondents were chronic diseases as many as 18 respondents.

Table 4 Distribution of Respondents Based on Duration of Giving Therapy Through Intravenous Bolus

\begin{tabular}{cccc}
\hline No & $\begin{array}{c}\text { Duration of Intravenous } \\
\text { Bolus Therapy (Hours) }\end{array}$ & Frequency & Percentage \\
\hline 1 & $0-24$ & 0 & 0 \\
2 & $48-72$ & 22 & 42,3 \\
3 & $>72$ & 30 & 57,7 \\
\hline & Total & 52 & 100 \\
\hline
\end{tabular}

Shows that the majority of intravenous bolus therapy for respondents was $>72$ hours in 30 respondents.

Table 5 Phlebitis events in the Control Group

\begin{tabular}{|c|c|c|c|}
\hline No & Phlebitis Events & Frequency & Percentage \\
\hline 1 & Phlebitis & 22 & 84,6 \\
\hline 2 & No Phlebitis & 4 & 15,3 \\
\hline \multicolumn{2}{|c|}{ Total } & 26 & 100 \\
\hline
\end{tabular}

Shows that of the 26 respondents in the control group, almost all experienced phlebitis. And only 4 respondents did not experience phlebitis. 
Table 5 Phlebitis events in the Comparison Group

\begin{tabular}{cccc}
\hline No & Phlebitis Events & Frequency & Percentage \\
\hline 1 & Phlebitis & 2 & 7,6 \\
2 & No Phlebitis & 24 & 92,3 \\
\hline & Total & 26 & 100
\end{tabular}

Shows that of the 26 respondents in the comparison group, only 2 respondents experienced phlebitis and almost all did not experience phlebitis.

Table 8 Cross Tabulation of Phlebitis Events in the Control Group and Comparative Group

\begin{tabular}{ccccc}
\hline \multirow{2}{*}{ No } & \multirow{2}{*}{ Alcohol Swab } & \multicolumn{2}{c}{ Event } & \multirow{2}{*}{ Percentage } \\
\cline { 3 - 4 } & & Phlebitis & $\begin{array}{c}\text { No } \\
\text { Phlebitis }\end{array}$ & \\
\hline 1 & Phlebitis & 2 & 24 & 26 \\
2 & No Phlebitis & 22 & 4 & 26 \\
\hline & Total & 24 & 28 & 52 \\
\hline \multicolumn{2}{c}{ Chi Square Test } & $\boldsymbol{\rho}=\mathbf{0 , 0 0}$ & $\boldsymbol{\alpha}=\mathbf{0 , 0 5}$ & $\mathbf{x ~ 2 = 1 7 , 3 3 3}$ \\
\hline
\end{tabular}

Shows that of the results of a statistical test using the SPSS for Windows program with Chi Square test based on a significance test of $5 \%(0.05)$ found $x 2=17.333$ and $\rho=0.00$ means that it affects the alcohol swab infection when injecting bolus intravenously.

\section{DISCUSSION}

Occurrence of ephebitis at the time of injection of intravenous without using alcohol alcoholic swabs. Based on the table of 5 , the number of respondents in the control groups that did not use alcohol swab almost all corresponded to phlebitis (84.6\%) and only a small proportion did not have phlebitis (15.3\%).

This is in accordance with the theory of INS (2011) that phlebitis is marked by one or more signs of phlebitis, which is redness, pain, induration, extreme heat or heat, and swelling in the area of puncture. Inflammation of phlebitis is derived from the mechanism of irritation that occurs in the tunic endothelium of the intima vein and attachment to the platelets in the area.

Whereas according to Darmadi (2008), disinfection is the process of removing organic organisms in objects that do not live with the exception of endosporabacteria. Disinfection is also said to be an action taken to kill pathogens and aphrodisiacs which do not kill the spasms contained in medical devices. Desinfection is carried out using the infectious agent through washing, polishing, soaking and drying it with the aim of preventing the infection.

Because open injection sites are one of the places where bacteria and bacteria can result in phytopitis, which is marked by a reddish and warm area around the hemorrhoid, along the veins, pain or soft feeling in the area of stabbing or along the veins, and swelling. Phlebitis itself is a venous inflammation caused by irischemistry, germs, bacteria and drugs which are given intravenous fluids, Phlebiris caused by the fact that bacteria and bacteria are confused with the technique of using disinfection that is inadequate in the action of good tools used and actions for patients.

With this, it can be ensured that giving essential alcohol swab is done to ensure that the area to be injected is free of bacteria which can cause irritation to the skin. in patients alcoholic swabs are one of the infections that can reduce microorganisms in non-living objects.

From the data 5 numbers of respondents who were not alcoholic swabs when intravenous bolus injection did not occur in phlebitis as many as 4 respondents (15.3\%) and from table 1 showed a discussion of large numbers of patients with 20-39 years of 30 respondents (30\%).

This is in accordance with the theory of Sabiston, David, 1995 in Dewi (2008) that the skin poses an organ in the human body that limits the outer environment. One of the functions of the skin is a system that protects the body of the body of the enemy.

Skin tend to include physical nonspecific system parts. leather can do its function as a defense system with some process. In their own skin, they are already able to work hard and attack objects.

The cell is known as the Langerhans cell found in the epidermal layer. Then, there is a process on the skin that continues to occur with a constant cycle (except for psoriasis) every 28 days. This process is referred to as desquamation.

Desquamation is the process of releasing the komeum stratum which has died and will be upgraded to a new skin. This 
process is intended to remove microorganisms that can attach to the skin (stratum komeum), also known as gelatinization. In addition, there are also items. it is an anti-fungal substance, namely unsaturated transformers. The wrong factors that influence the system are:

a. Age

There is an ability to witness that it is facing the invading microorganisms. It is necessary to experience impaired production of $B$ and $T$ lymphocytes. While thin, notelastic skin, peripheral neuropathy, reduce sensitivity to accompanying circulation.

b. Gender

Estrogen modulates superior T-cell specific lymphocytes, activates the population of $B$ cells associated with autoimmune expressing CD5 markers, tends to stimulate immunity, androgens retain the production of IL2 and suppresses more sexually active T cells in women associated with estrogen.

Age and sex affect the immune system on the skin because older skin can decrease the body's defense so that phlebitis is easier, while sex affects due to the presence of different hormones in women and men, women are more easily decreased, hormones in men tend to promote immunity and maintain IL-2 production.

Occurrence of Plebitis Given Alcohol Swab Disinfection, Based on table 6 shows that the respondent in alcoholic swabs when injecting through an intravenous bolus almost all of them is phlebitis (92.3\%) and partly phlebitis (7.6\%).

According to Darmadi (2008), disinfection is the process of removing organic organisms in objects that do not live with the exception of endosporabacteria. Disinfection is also said to be an action taken to kill pathogens and aphrodisiacs which do not kill the spasms contained in medical devices.

According to Suparyanto (2011), the advantage of alcohol use is that people can inhibit the growth and proliferation of many types of microorganisms, including bacteria, fungi, viruses, and protozoa, but weakness in the use of alcoholic infections is not consistent with alcohol consumption. Desinfection is carried out using the disinfectant through washing, polishing, soaking and drying it with the aim of preventing infection.

Because alcohol swabs are one of the infections that can reduce microorganism in non-living objects, using infected alcohol swabs when giving injections through an intravenous bolus can prevent the occurrence of phlebitis marked with a reddish and warm area around the intestine or veins, pain or soft feeling in the stab area or veins, and swelling.
Effects of Disinfection (Alcohol Swab) When Giving Intravenous Bolus Injection With Phlebitis, After conducting the study and doing the description, it is often obtained as explained in table 7 which shows that in patients who do not get treatment / control groups that occur in phlebitis (85\%) and not phlebitis (15\%). Whereas those who experience treatment / alcohol swab occur phlebitis (8\%) and do not develop phlebitis (92\%).

From the results of statistical tests using the SPSS for windows program with the Chi-Squar test based on the significance test $\alpha$ $=5 \%(0.05)$, it is obtained that $=0.00$ which means that $\mathrm{HO}$ is rejected, meaning alcohol swab infection affects the incidence of phlebitis when intravenous bolus injection in patients receiving therapy.

According to Brunner and Suddarth (2001) in Kristina (2011), the causes of phlebitis are chemical properties, physical and factor factors. One of the bacterial factors is the technique that is inadequate both in the physical area and the equipment used. This can lead to infiltration of blood flow that causes phlebitis.

Disinfection is the act of killing peptogens and what are the meanings of their consumption on treatment devices or on the surface of the tissue by using disinfectants or transmitting washing, polishing, soaking, and drying equipment. The purpose of infection is to prevent the occurrence of infection in invasive measures (eg, attachment of the catheter, infusion, administration, etc.).

Each with the concept above that, the provision of alcohol swab infection can be used to prevent the occurrence of phlebitis. In table 5 , it shows almost all disinfected respondents in alcohol swabs occur phlebitis. Use of gold can inhibit growth and proliferation of various types of microorganisms, including bacteria, fungi, viruses, and protozoa which can prevent phlebitis from occurring. In table 6 patients who were swab alcoholic disinfected decreased almost according to him without phlebitis.

Use of Disinfection Alcohol swabs can prevent the occurrence of phlebitis because of inhibiting the growth and proliferation of many types of microorganisms, including bacteria, fungi, viruses, and protozoa.

\section{CONCLUSION}

1. Almost all patients who were given alcohol swabs when intravenous bolus injection did not occur phlebitis.

2. Almost all patients who are not given alcohol swabs when injecting intuvena bolus occur plhebitis. 
3. There is an effect of alcohol swab during intravenous bolus injection with the occurrence of plebebitis.

From a number of descriptions of the discussion and conclusions described above, there are a number of suggestions given for consideration by health professionals: For Nurses and Health Workers It is expected that nurses in administering drugs intravenously must be more thorough in accordance with the correct procedure, namely the principle of $6 \mathrm{~T}$ dun 1W. Always maintain aseptic and disinfection techniques, observe for signs and symptoms of plhebitis.

\section{REFERENCES}

Alexander, M, Corrigan, A, Gorski, L, Hankins, J., \& Perucca, R. (2010). Infusion nursing society, Infusion nursing: An evidence-based approach (3rd Ed.). St. Louis: Dauders Elsevier.

Alexander, M, Corrigan, A, Gorski, L, Hankins, J., \&Perucca, R. (2010). Infusion nursing society, Infusion nursing: An evidence-based approach(3rd Ed.). St. Louis: Dauders Elsevier.

Ari, Elizabeth, dkk. 2009. Perbedaan Tehnik Mendesinfeksi Alkohol 70\% Antara Cara Spray Dengan Oles Saat Pemasangan Infus Dalam Menurunkan Jumlah Bakteri Pada Site Infuse Di Rumah Sakit Santo Yusup Bandung. Media NelitiVolume 10 No. XIX Oktober 2008-Februari 2009.

Asmadi. 2008, Konsep Dasar Keperawatan. Jakarta : EGC.

Asmadi. 2008. Teknik Prosedural Keperawatan: Konsep dan Aplikasi. Jakarta : EGC.

Berman, Shirlee J. Synder, BarbaraKozier dan GlenoraErb, 2009.Buku Ajar PraktikKeperawatanKlinis. Jakarta : EGC.

Culverwell, E.(2013). Pheriferal intravenous cannulation self learning package. Canterbury District Health Board.

Darmadi. $2008 . \quad$ InfeksiNosokomial :Problematika Dan Pengendaliannya. Jakarta :Penerbit Salemba Medika.

Depkes RI, (2013). Tentang infeksi nosokomial di Rumah Sakit.

Dewi, Siti Fitria. 2008.Insidensi Fibroadenoma Di RumahSakit Immanuel Bandung
Periode 2005-2006. Undergraduate thesis, Universitas Kristen Maranatha.

Elmiyasna, dan FitrianaJuvita. 2012. HubunganPenerapanKewaspadaanSta ndarDenganKejadianInfeksi

KarenaJarumInfus (Phlebitis)Di Irna Non BedahRsup. Dr. M. Djamil PadangTahun 2012. STIKes Mercubakti Padang.

Graber, M.A. Prof. 2010. TerapiCairan, Elektrolit dan Metabolik Edisi 3.Farmedia. Jakarta.

INS. 2011. Infusion nursing standar of practice. Journal of infusion nursing.

Iradiyanti, WindaPratama dan ErlinKurnia. 2013. Pemberian Obat Melalui Intravena terhadap Kejadian Phlebitis pada Pasien Rawat Inap di rumah Sakit. Jurnal STIKes Volume 6 No 1, Juli 2013.

Istiroha, dan Hanik Erfatunafiah. 2017. Faktor Lama Hari Pemasangan Infus Tidak Berhubungan dengan Kejadian Phlebitis. Jurnal of Ners Community: Volume 08, No. 02, November 2017

Kristiana, Nita Sukma(2011) Asuhan Keperawatan Pada Ny. S Dengan Gangguan Sistem Reproduksi : "Kanker Serviks" di Bangsal Mawar III RSUD Moewardi Surakarta. Skripsi thesis, Universitas Muhammadiyah Surakarta.

National health service United Kingdom. Chemotherapy [Internet]. [cited 2019 feb 18]. Available from: http://www.nhs.uk/conditions/chemo therapy/Pages/Definition.aspx

Potter, P. A., \& Perry, A. G. 2009. Fundamental Keperawatan buku 3 edisi 7. Jakarta: Salemba Medika.

Potter, P. A., \& Perry, A. G. 2010. Fundamental Keperawatan buku 3 edisi 7. Jakarta: Salemba Medika.

Setyowati. 2011. Hubungan Frekuensi Pemberian Obat Secara Intravena dengan Kejadian Phlebitis. Akademi Keperawatan Pemerintah Kabupaten Gresik.

Supriyanto. 2011. Konsep Dasar Desinfektan. http://dr- 
suparyanto.blogspot.com/2011/03/ko nsep-desinfektan.html.

Tirmanidhana, Fitrahmadani dkk. 2018. Analisis Pelaksanaan Pencegahan dan Pengendalian Infeksi Nosokomial Di ICU RSUD Labuang Baji Makassar. Higiene : Volume 4 No. 2 Mei-Agustus 2018.
Wahyunah, dkk. 2013. Pengetahuan Perawat tentang Terapi Infus Memengaruhi Kejadian Phlebitis dan Kenyamanan Pasien. Jurnal Keperawatan Indonesia, Volume 16 No. 2, Juli 2013. 